\title{
Pattern separation is not affected by granule cell threshold independent of its effect on sparseness
}

\author{
Jossina Gonzalez ${ }^{1 *}$, Brian Derrick ${ }^{1,2}$, Todd Troyer ${ }^{1,2}$ \\ From Nineteenth Annual Computational Neuroscience Meeting: CNS*2010 \\ San Antonio, TX, USA. 24-30 July 2010
}

Mounting evidence indicates that the dentate gyrus functions as the computational locus of pattern separation [1-5], a phenomenon thought to be crucial for associative memory functions in area CA3 [6-11]. Pattern separation enables the decorrelation of highly overlapped input patterns arising from the perforant path via the formation of sparse, uncorrelated outputs $[4,5]$. Several anatomical and physiological properties of the dentate have been proposed to mediate pattern separation, including input expansion [11]. A series of simple models consisting perforant path (PP) inputs and granule cells (GCs) were employed to investigate whether granule cell threshold contributes to pattern separation independent of its effect on the sparseness of GC activity. Input connections were binary and chosen independently for each possible PP-GC pairing. Simulations included eight input patterns, each consisting of seven active PP elements, where input patterns 1 and 2 are highly overlapped and patterns 1 and 8 have no overlap. The percent overlap was defined as the ratio of co-active elements across pattern pairs relative to the total number of active elements in each pattern. Pattern separation was defined as a reduction in percent overlap for the output relative to the input. In accord with previously published models using $\mathrm{k}$-winner take all dynamics [1], our results reveal that increasing GC threshold increased pattern separaration, but increasing the size of the granule cell population did not. However, if an increase in GC threshold was accompanied by an increase in connection probability in such a way to maintain the probability of GC activation, the percent overlap in the GC output remained unchanged. Therefore, changing a fixed granule cell threshold does not affect pattern separation

\footnotetext{
* Correspondence: pkn986@my.utsa.edu

${ }^{1}$ Department of Biology, University of Texas at San Antonio, San Antonio, TX 78249, USA
}

independent of its effect on the sparseness of GC activity. The effective threshold of granule cells may be regulated by a number of mechanisms, including synaptic scaling and metaplasticity. We are currently investigating how such changes, which introduce dependencies between connection strength and patterned activity, might contribute to pattern separation across a series of afferent inputs.

\section{Acknowledgements}

Dr. Todd Troyer and Dr. Brian Derrick for their support and guidance. Supported by NIH/NGMS MBRS-RISE GM60655.

\section{Author details}

${ }^{1}$ Department of Biology, University of Texas at San Antonio, San Antonio, TX 78249, USA. ${ }^{2}$ Neurosciences Institute, University of Texas at San Antonio, San Antonio, TX 78249, USA.

Published: 20 July 2010

\section{References}

1. O'Reilly RC, McClelland JL: Hippocampal conjunctive encoding, storage, and recall, avoiding a trade-off. Hippocampus 1994, 4(6):661-682.

2. Gilbert PE, Kesner RP, Lee I: Dissociating hippocampal subregions: a double dissociation between dentate gyrus and CA1. Hippocampus 2001, 11(6):626-636.

3. Leutgeb JK, Leutgeb S, Moser MB, Moser El: Pattern separation in the dentate gyrus and CA3 of the hippocampus. Science 2007, 315(5814):961-966.

4. Bakker A, Kirwan CB, Miller M, Stark CEL: Pattern separation in the human hippocampal CA3 and dentate gyrus. Science 2008, 319(5870):1640-1642.

5. Myers CE, Scharfman HE: A role for hilar neurons in pattern separation in the dentate gyrus: a computational approach. Hippocampus 2009, 19(4):321-337.

6. Marr D: Simple memory: a theory for archicortex. Philos Trans $R$ Soc Lond B Biol Sci. 1971, 262(841):23-81.

7. Derrick BE: Plastic processes in the dentate gyrus: a computational perspective. Prog Brain Res 2007, 163:417-451.

8. Rolls ET: Function of neuronal networks in the hippocampus and neocortex in memory. In: Byrne J and Berry W (Ed). Neural Models of Plasticity: Experimental and Theoretical Approaches San Diego: Academic Press. 1989, 240-265.

9. Rolls ET: A theory of hippocampal function in memory. Hippocampus 1996, 6(6):601-620. 
10. Rolls ET, Treves A: Neural networks in the brain involved in memory and recall. Prog Brain Res 1994, 102:335-341.

11. Rolls ET, Treves A: The Hippocampus and Memory. Neural Networks and Brain Function Oxford University Press: Oxford, UK 1998, 95-135.

doi:10.1186/1471-2202-11-S1-P123

Cite this article as: Gonzalez et al:: Pattern separation is not affected by granule cell threshold independent of its effect on sparseness. BMC

Neuroscience 2010 11(Suppl 1):P123.

Submit your next manuscript to BioMed Central and take full advantage of:

- Convenient online submission

- Thorough peer review

- No space constraints or color figure charges

- Immediate publication on acceptance

- Inclusion in PubMed, CAS, Scopus and Google Scholar

- Research which is freely available for redistribution

Submit your manuscript at www.biomedcentral.com/submit
C Biomed Central 